WU Jian, FU Guoqun

\title{
The effects of brand origin country and made-in country on consumers' product evaluations and purchase intention
}

(C) Higher Education Press and Springer-Verlag 2007

\begin{abstract}
This research explores the different effects of brand origin country and made-in country on consumers' product evaluations and purchase intention. It is found that made-in cues have significant impacts on quality evaluation while brand origin cues influence purchase intention more prominently. Product quality is perceived lower when a brand from developed country is manufactured in developing countries, however, this may not affect consumers' purchase intentions.
\end{abstract}

Keywords brand origin country, made-in country, product evaluation, purchase intention

摘要 在区分品牌来源国和产品制造国的基础上, 探索它们对消费者在产品 质量评价和购买意愿方面的影响, 可以发现：产品制造国对品质评价具有显著影 响, 而品牌来源国则对购买意向产生显著作用。将品牌来源国形象高的产品转移 到发展中国家生产, 有可能降低产品的品质感知, 但不一定影响消费者购买意 愿。

关键词品牌来源国, 产品制造国, 质量评价, 购买意愿

\section{Introduction}

On the global market, more and more brands originated from developed countries are manufactured in developing countries. Nike, for example, an US brand, now

Received December 20, 2006

WU Jian ( $₫)$, FU Guoqun

Guanghua School of Management, Peking University, Beijing 100871, China

E-mail:wujian1@gsm.pku.edu.cn 
is widely manufactured in China and Brazil. Similarly, the separation of made-in country and brand origin country is witnessed by every product category, from home appliances, automobiles to fast moving consumer goods. Several important research questions arise: how do consumers evaluate these "hybrid" products? Will the incongruity between made in countries and brand origin countries lower consumers' product quality perceptions? Will consumers' purchase intention be affected accordingly?

There is a huge stream of researches on the effect of country of origin in the literature. Early studies indicated that consumers made different evaluations on products from different countries (Schooler, 1965). Many researchers replicated the results in different cultural contexts (Erickson et al., 1984; Ettenson, 1993; Liefeld et al., 1996). Although consensus on the effect of country of origin emerged (Bilkey and Nes, 1982; Peterson and Jolibert, 1995), the underlying mechanisms of how consumers process country of origin information are somewhat controversial. Some researchers contended that country of origin is used by consumers as the signal of product quality (Han, 1989; Johansson, 1989); some argued that country of origin influences consumers by being used as product attribute (Hong and Wyer, 1989); others insisted that country of origin affects consumers' product evaluation through ethnocentrism or animosity (Klain and Ettenson, 1999).

Traditionally, country of origin is synonymous with made-in mountry, which is defined as the country where a company's headquarters are located (Johansson, 1989). With more and more "hybrid" products emerging, some researchers proposed to use "country of manufacture," "country of design," "brand origin country" instead of the traditional country of origin concept (Chao, 1993; Ettenson, 1993; Nebenzahl et al., 1997). Brand origin country refers to the country with which consumers associate the brand. For example, when mentioning Coca-Cola, McDonald, and Kodak, most consumers will view them as American brands; when talking about Sony, Panasonic, and Honda, consumers will think them as Japanese brands. Some researchers argued that Brand origin country represents a particular culture, reflects consumers' attitude to a specific country, and therefore, will affect consumers' behavior to a large degree. Phau and Prendergast (2000) claimed that consumers get used to the reality that products bearing the same brand are not necessarily made in their origin country. Under strict supervision and control, the qualities of these products are guaranteed. For this reason, made-in countries may not be as important as they were some years ago. On the other hand, brand origin countries may become more salient and influential because they can arouse consumers' emotions and associations linked to particular country or culture.

Previous studies focused on how country image or made-in countries influence consumers' product evaluations, and the separate effects of made-in country 
and brand origin country are not distinguished (Mahaswaran, 1994). This may cause the following two problems. First, the effect of made-in countries may be exaggerated due to the non-separation of brand origin country effects from made-in country effects. Second, the mechanisms by which the two types of countries influence consumers may differ. It is argued that the made-in country represents a country's economic or technological development level, and plays an important role in product quality evaluation while a brand origin country is associated with specific cultures or lifestyles desired by consumers, and it may add value not necessarily via enhancing perceived quality of the products.

This study attempts to explore the effects of brand origin country and made-in country on consumer's product evaluation and purchase intention in terms of the China's market situation and Chinese consumers. At that same time, this study will explore that whether there is significant interaction between brand origin country and made-in country, and whether the effects of both vary with the price of the products. More specifically, it aims at answering the following three questions: (1) in what ways do brand origin country and made-in country influence consumer's purchase behavior? (2) are there any interaction effect between brand origin country and made-in country? (3) will price moderate the effect of brand origin country?

\section{Hypotheses}

In literatures, it is well documented that country image serves as a prototype and biases consumer's product evaluation and choices either in general level or in specific product category level (Reierson, 1967). For example, some researchers found that products made in developed countries are better evaluated than those in developing countries in general. In China, many consumers like Japanese electronics more than those from other countries. They not only care about the origin of brand but also pay much attention to made-in country of the product. Therefore, if a Japanese branded product like Sony TV is made in a less developed country such as China, consumers may have a lower perceived quality, and are less likely to be willing to pay a premium price. However, as consumers increasingly know that most of Sony TV products are not made in Japan, and that those products may be better in terms of after sale services or total value, their purchase willingness may not necessarily decrease.

Hypothesis 1 When the manufacturing of the same brand is transferred from developed countries to developing countries, consumer's product quality perception will be lowered, but purchase intention may not be affected.

Phau and Prendergast (2000) contended that consumers associate a brand with its origin country even they are aware that in most cases the brand product is not 
made in its origin country. Due to this, brand origin country is conceptually very different from made-in country. For example, although Honda or Buick is made in China, consumers can readily identify the former as Japanese brand and the latter as American brand. More importantly, consumers will automatically associate "mileage economy" or "delicacy" to Honda, "capaciousness" or "solid" to Buick. These associations will color consumers' product evaluation and choice decisions as well. Batra et al. (2000) found that Indian consumers prefer to choose western brands, not only for the sake of high quality, but also for the desire of conspicuous consumption and expressions to western lifestyles (Batra et al., 2000).

Obviously, the classification of developed and developing countries is not able to capture the richness of country of origin, because it cannot tell the image distinctions of different developed or developing countries. For example, although both Switzerland and the USA are developed countries, Switzerland has a high reputation for its high quality watch industry while the USA does not. On the contrary, American sport shoes are highly regarded in Chinese market, but Switzerland's are not. As each country has its own resource and economic structures, its unique social and cultural history, the brands originated from it may be inevitably embedded with all these traces. Therefore, it is argued that the country of brand origin will stimulate consumers' associations related to a country's relative advantages and status of a particular industry as well as the social and cultural aspects of the country which may add value to branded products. On the other hand, made-in country reflects a country's economic or technological development level, and it may signal a country's manufacturing expertise and abilities.

Brand origin country can be specific depending on product type. For example, Japan has good brand origin country image in automobile and electronics; and America is looked on as good brand origin country of sport shoes and soft beverage. In a word, brand origin country can influence consumer's product quality assessment. A good brand origin country image will lead to a better evaluation, subsequently a stronger purchase intention.

Hypothesis 2 Brand origin country can influence consumer's product quality perception and purchase intention. A good brand origin country image will lead to better product quality perception and stronger purchase intention; a bad brand origin country image will lead to worse product quality perception and weaker purchase intention.

The effect of brand origin country should be separated from the mixed effect because it influences consumers differently from made-in country. Examining the relationship between them can help deeper understand the similarity and distinction between them. In general, a good brand origin country image originates 
from a good made-in country image. When the products bearing a good brand origin country image are manufactured in countries with bad made-in country image, consumer's product quality perception will be lowered, and purchase intention will be weakened.

Hypothesis 3 When products of good brand origin country image are manufactured in developing countries, consumer's product quality perception will be lowered and purchase intention will be weakened; when products of bad brand origin country image are manufactured in developing countries, consumer's product quality perception and purchase intention will not be changed.

In this research, the price factor was included in the experimental design. Early researches on the effect of price can be traced to Leavitt's study. He found in his experiment that consumers did not always select the brand with cheaper price. Leavitt (1954) contended that "price itself may have more than one meaning to a consumer (p. 210) (McConnell, 1968)". After Leavitt's (1954) study, McConnell (1968) explored empirically the relationship between price and perceived quality; he found that the price is used as an indicator of product quality. In his experiment, although the stimuli-beer was physically identical, respondents perceived the quality significantly different with different prices. Researchers also found that the price can influence consumers' purchase choices. Using seven widely marketed product lines, Lambert (1972) found that price can influence consumers' choice behavior; different groups of consumers can have different confidence in their judgment of the relationship between price and product quality, which will influence their choice of different priced brands of the same product line (Lambert, 1972).

Although many researches have been carried out on the relationship between price and perceived quality, the results are mixed, and an integrative conceptual framework is needed to explain the inconsistent findings. On the basis of past studies, Zeithaml (1988) summarized the relationship of price, perceived quality, and perceived value into a mean-end model (Zeithaml, 1988). Borrowing empirical evidence from relevant research and his exploratory study, he concluded that the factors affecting usage of price as quality indicator can be grouped into informational factors, individual factors, and product category factors. Other researchers intended to explore the effect of price from a broader perspectiveextrinsic cues. For example, under multiple cues situation, Rao and Monroe (1989) found that other cues may enhance price's effect on perceived quality. Furthermore, Dodds et al. (1991) advanced a conceptual framework including multiple extrinsic cues, perceived quality, perceived value and willingness to buy and empirically test the relationship between them. They found price has a positive effect on perceived quality and negative effect on perceived value and willingness to buy. 
Recently, country of origin has been viewed an important extrinsic cue in international marketing. As an extending of Dodds et al.'s research, Teas and Agarwal (2000) explored the effect of price, brand name, store name, and country of origin on perceived quality, perceived sacrifice, and perceived value. They found even other three extrinsic cues - brand name, store name, and country of origin were available, there was a significant positive relationship between price and perceived quality. From relevant literature, it is obvious that as an important extrinsic cue, price should be included into this research. Furthermore, general construct - country of origin - into brand origin country and made-in country is partitioned in this study, so this research can be expected to provide new understanding of the effect of price. Starting from previous literature on the effect of price, it is hypothesized that

Hypothesis 4 Price will moderate the effect of brand origin country. At high price level, good brand origin country image will lead to better product quality perception and stronger purchase intention than bad brand origin country image; at low price level, brand origin country image will not influence consumer's product quality perception and purchase intention.

\section{Methods}

\subsection{Stimuli and experimental design}

Two stimuli are used in the experiment: watches and sport shoes. About watches, an artificial brand name Vilex is developed. We use Swiss to represent good brand origin country image and America represents bad brand origin country image on the basis of pretest. Swiss (America) is selected as the developed countries and China as the developing country. On the basis of pretest, two price levels are employed: 1680 and 380 RMB. About sport shoes, an artificial brand Hieed is used. Different from design in watches, America represents good brand origin country image, and Swiss represents bad brand origin country image. America (Swiss) represents developed country and China represents developing country. Depending on the results of pretest, two price levels are selected: 980 and 280 RMB. The whole experimental design is showed in Table 1.

The questionnaire includes three parts. First, the pictures of watches or sport shoes, brand names, brand origin country, made-in country, and price information are presented. In the following part, respondents are asked to provide their product quality perception, value perception, and purchase intention. Respondents' demographic information is collected at last.

A pretest was conducted to guarantee that the manipulation was successful. In pretest, 31 respondents whose demographic characteristics were similar to the 
Table 1 Factorial design in this study

\begin{tabular}{lcc}
\hline Brand origin country & Made-in country & Price \\
\hline Swiss & Swiss & High \\
Swiss & Swiss & Low \\
Swiss & China & High \\
Swiss & China & Low \\
America & America & High \\
America & America & Low \\
America & China & High \\
America & China & Low \\
\hline
\end{tabular}

respondents in experiment were sampled. They are asked to provide their attitude to America and Swiss when these two countries are brand origin country of watches and sport shoes. To eliminate expectation bias, China and Japan were added. The respondents were asked to provide their opinions on the following statements with seven-point Likert scale: (1) (country) has good reputation on manufacturing high quality watch (sport shoes); (2) most good brands of high quality watch (sport shoes) come from (country); (3) (country's) watch (sport shoes) has good reputation in the world; (4) most people are pride of owing watch (sport shoes) brands from (country). The two ends of the scale represented "completely agree" and "completely disagree." The results indicated that Swiss and America represent good brand origin country image of watch and sport shoes separately as expected. Respondents' assessment on Swiss was 6.33 when it was the brand origin country of watch, significantly higher than America (2.45) $(t=17.71, p=0.000)$; on the contrary, when as the brand origin country, America (5.34) got significantly higher assessment than Swiss (2.24) $(t=-8.61$, $p=0.000)$.

\subsection{Measurement}

In this research, brand origin country, made-in country, and price are independent variables that are manipulated on the basis of pretest. Dependent variables are consumer's quality perception and purchase intention. The scale of Dodds et al. is borrowed, and some modifications are made (Dodds, Monroe, and Grewal, 1991). Specifically, quality perception is measured through consumer's perception of product reliability, workmanship, and overall quality perception. When measuring purchase intention, two situations should be differentiated: buy for oneself and buy as a gift because some researchers have found that these two situations may affect consumer's purchase intention significantly (Belk, 1975). All the constructs are measured with seven-point Likert scale. About watches, the reliability coefficients (Cronbach alpha) of perceived quality and purchase 
intention are 0.79 and 0.82 ; about sport shoes, the coefficients are 0.82 and 0.86 respectively, so the items' score is simply averaged.

\subsection{Data collection}

The data were collected in railway station and one shopping mall. In the collected 408 questionnaires, 360 questionnaires were valid. In the respondents, male accounted for $48.2 \%$, and female $51.8 \%$. The percentage of the respondents less than 20 years old was $13.3 \%$, between 20 and 40 was $73 \%$, between 41 and 55 was $11.4 \%$, older than 56 was $1.7 \%$. Most respondents got undergraduate education (38.3), 15.6\% had received graduate education, and about $27.8 \%$ accepted education of high school or less.

\section{Results}

\subsection{Manipulation check}

In this study, artificial brand names were used to eliminate bias of brand familiarity. As expected, $78.19 \%$ respondents do not know Vilex brand; $82.25 \%$ do not hear of Hieed.

The results indicate that manipulation of price is successful. Respondents perceive price level as expected. The perceived high price levels (4.67 for watch and 4.81 for sport shoes) are significantly higher than low price level (4.18 for watch and 4.15 for sport shoes).

\subsection{Product quality evaluation}

Consumer's expertise has been found to affect their cue utilization when they make product quality evaluation (Rao and Monroe, 1988). Therefore, we use covariance analysis to eliminate the effect of consumer's expertise. The results show in Tables 2 and 3.

Table 2 Consumer's watch quality evaluation (mean and variance)

\begin{tabular}{lcccccc}
\hline & \multicolumn{2}{c}{ Swiss brand } & & \multicolumn{2}{c}{ American brand } & \\
\cline { 2 - 3 } & Made in Swiss & Made in China & & Made in America & Made in China & \\
\hline Low price & $4.60(0.91)$ & $4.33(0.67)$ & & $4.48(0.66)$ & $4.58(0.81)$ & $4.50(0.77)$ \\
High price & $4.93(0.86)$ & $4.30(0.85)$ & & $4.67(0.68)$ & $4.70(0.92)$ & $4.65(0.85)$ \\
& $4.77(0.89)$ & $4.32(0.76)$ & & $4.57(0.67)$ & $4.64(0.86)$ & \\
& $4.54(0.85)$ & & $4.61(0.77)$ & $4.57(0.81)$ \\
\hline
\end{tabular}


Table 3 Consumer's sport shoes quality evaluation (mean and variance)

\begin{tabular}{lcclccc}
\hline & \multicolumn{2}{c}{ Swiss brand } & & \multicolumn{2}{c}{ American brand } & \\
\cline { 2 - 3 } & Made in Swiss & Made in China & & Made in America & Made in China & \\
\hline Low price & $4.39(1.04)$ & $4.19(0.78)$ & & $4.43(0.64)$ & $4.33(0.81)$ & $4.34(0.82)$ \\
High price & $4.56(0.86)$ & $4.38(0.81)$ & & $4.58(0.73)$ & $4.27(0.83)$ & $4.44(0.81)$ \\
& $4.47(0.95)$ & $4.28(0.79)$ & & $4.51(0.68)$ & $4.30(0.81)$ & \\
& $4.38(0.87)$ & & $4.40(0.75)$ & $4.39(0.81)$ \\
\hline
\end{tabular}

The results reveal that made-in country affects consumer's product quality evaluation significantly $(F=3.351, P=0.068)$. Consumer's watch evaluation is significantly lowered when made-in country is changed from developed country (Swiss) to developing country (China). Similarly, the analysis of consumer's sport shoes quality evaluation indicates that the effect of made-incountry is significant. Above results provide part support for $\mathrm{H} 1$.

The covariance analysis indicates that brand origin country does not influence consumer's product quality evaluation significantly, not consistent with the hypothesis.

It is found that the interaction effect between brand origin country and made-in country on watches' quality evaluation is significant $(F=6.19, P=0.014)$, but not on sport shoes' evaluation $(F=0.007, P=0.936)$. As Fig. 1 shows, consumer's watch quality evaluation is significantly lowered when Swiss brand is manufactured in China comparing with in Swiss; meanwhile, consumer's watch quality evaluation does not change significantly when American brand is made in China comparing with in America.

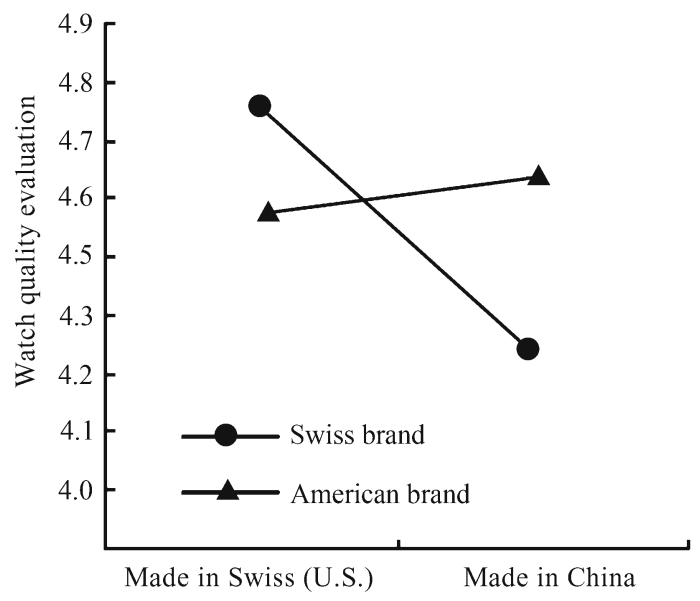

Fig. 1 The interaction between brand origin country and made-in country on consumer's watch quality evaluation 
It has not been found that there is significant three-way interaction among brand origin country, made-in country and price.

\subsection{Purchase intention}

Purchase intention is different from product quality evaluation, which is found to be directly influenced by product perceived value (Dodds et al., 1991) and highly associated with consumer's real purchase behavior. Some researchers found that situation influence consumer's purchase intention. One important situation factor is "buy for oneself" or "buy as gift" (Belk, 1975), which is salient especially in China. Therefore, the situational factor was taken into consideration in the experimental design, specifically, two scenarios were designed in the experiment, one is "buy for yourself," the other is "buy as a gift." The results are shown in Tables 4 and 5 .

It is found that consumer's watch knowledge $(F=25.838, P=0.000)$, price level $(F=9.416, P=0.002)$, and situational factor $(F=50.011, P=0.000)$ all have significant influence on consumer's watch purchase intention. Consistent with $\mathrm{H} 2$, brand origin country $(F=6.814, P=0.009)$ affects consumer's watch purchase intention, but the significant effect of made-in country $(F=1.342$, $P=0.247$ ) on consumer's purchase intention is not found, which does not support $\mathrm{H} 1$.

The results indicate that the interaction between brand origin country and made-in country influences consumer's watch purchase intention at 0.10 significant level $(F=3.125, P=0.078)$ as Fig. 2 shows. It is worth noting that the direction of the interaction is not as expected. For good brand origin country image (Swiss brand), consumer's purchase intention is not significantly lowered when the brand is manufactured in China compared with Swiss; on the contrary, for bad brand origin country image (American brand), consumer's purchase intention is significantly weakened when the brand is made in China compared with America.

The significant interaction between brand origin country and price is not found.

The results of covariance analysis reveal that price $(F=11.98, P=0.001)$ and situational factor $(F=19.027, P=0.000)$ both significantly influence consumer's sport shoes purchase intention. Inconsistent with the hypotheses, the significant effect of made-in country and brand origin country is not found. Additionally, it is found that the interaction between brand origin country and made-in country has significant influence on consumer's sport shoes purchase intention ( $F=7.302$, $P=0.007$ ). As Fig. 3 shows, when brand origin country image is good (American brand), consumer's sport shoes purchase intention is significantly weakened when the brand is made in China compared with in America $(t=1.8240$, 

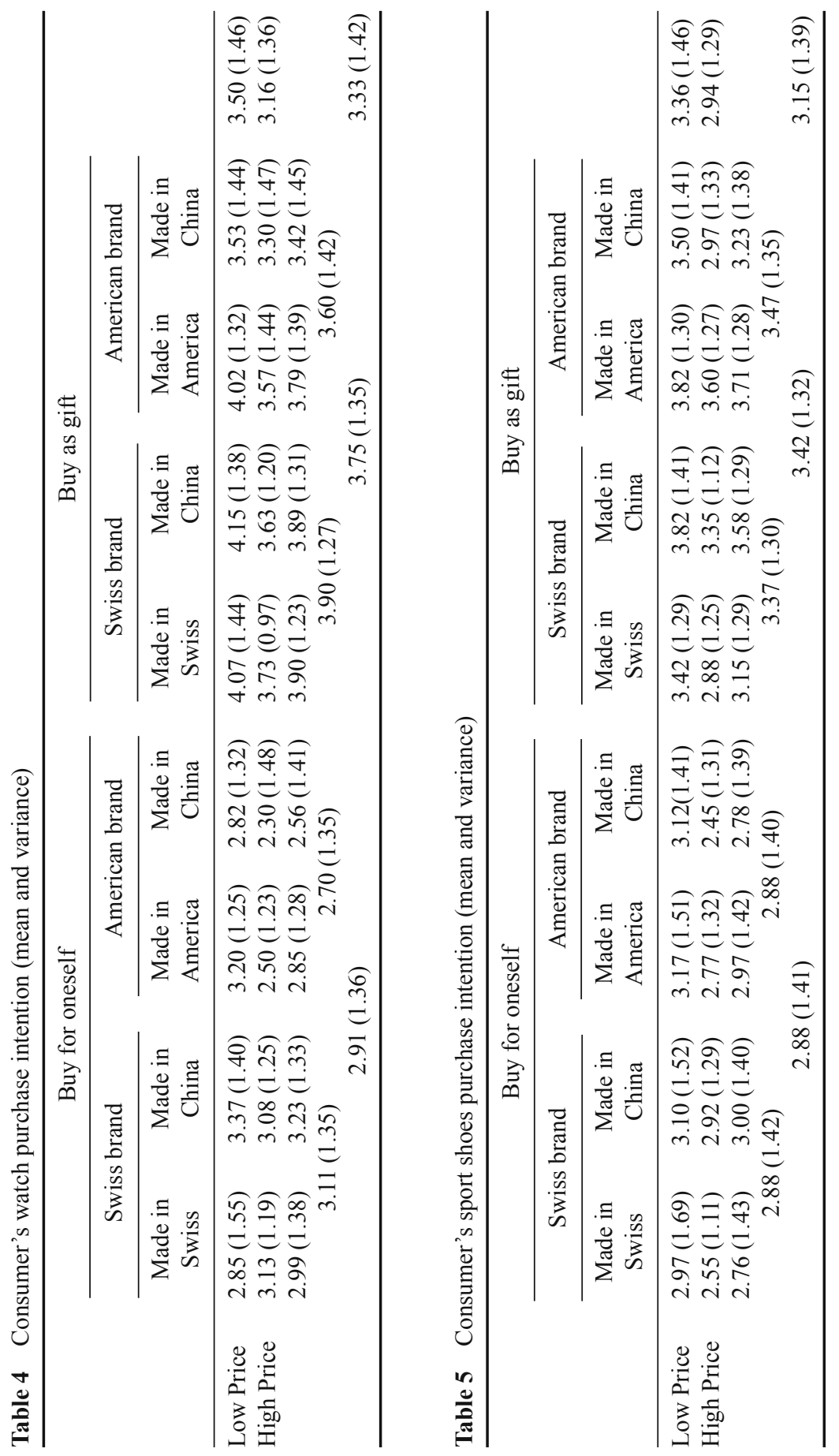


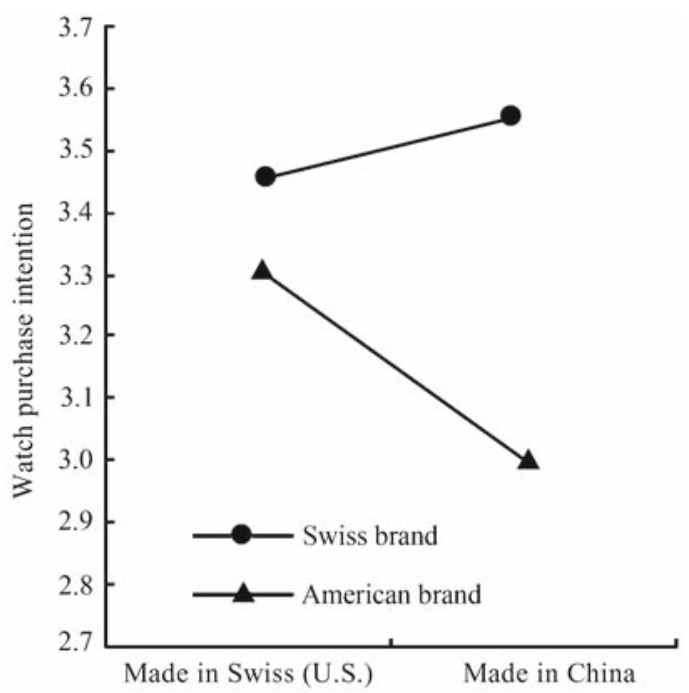

Fig. 2 The interaction between brand origin country and made-in country on watch purchase intention

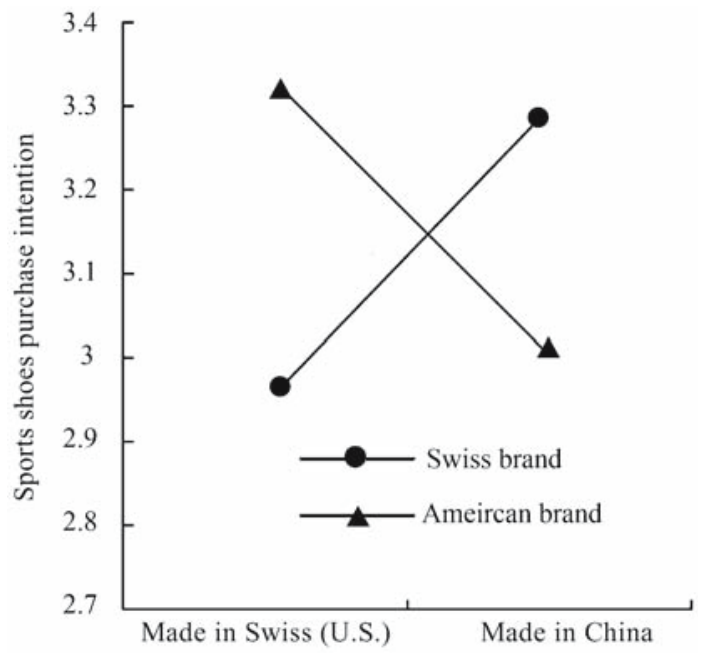

Fig. 3 The interaction between brand origin country and made-in country on sport shoes purchase intention

$P=0.0694$ ), which supports H 2; but unexpectedly, when brand origin country image is bad (Swiss brand), respondents indicate stronger purchase intention to the brand made in China than made in Swiss $(t=-1.9295, P=0.05)$. Meanwhile, it is found that when sport shoes are made in developed countries, consumer's sport shoes purchase intention of American brand is significantly stronger than 
Swiss brand $(t=-2.1438, P=0.0331)$; when sport shoes are made in developing country (China), consumers do not show significantly different purchase intention to the brands bearing different brand origin countries $(t=1.6084, P=0.1091)$.

The same as watch, it has not been found that there is significant interaction among brand origin country, made-in country, and price on consumer's sport shoes purchase intention.

\section{Discussion}

The results can be summarized in Table 6 .

Table 6 indicates that made-in country has significant influence on consumer's product quality evaluation, which is consistent with most studies in the literature. In traditional country of origin studies, most researchers focused on the effect of country of origin on consumer's product quality evaluation (Bilkey and Nes, 1982); and little research was conducted on the effect on consumer's purchase intention (Loureiro and Umberger, 2003). This research fills this gap. It is found that made-in country does not significantly affect consumer's purchase intention. The results indicate that the effect of made-in country on quality evaluation is not surely transferred to consumer's purchase intention. When we further our studies in future, we need to explore the effect of made-in country in a broader scope and get comprehensive understanding.

In this research, it is found that brand origin country does not influence consumer's product quality evaluation significantly; and just significantly affect watch purchase intention. Hypothesis 2 is just partly supported. A possible explanation is that brand origin country may not influence consumer's quality evaluation directly; it affects consumer's purchase intention through influencing consumer's perceived value. This cognition process is also supported in Dodds et al.'s study (1991). To test it, the data are reanalyzed with consumer's perceived value as dependent variable, the results is shown in Tables 7 and 8 .

The results indicate that brand origin country has significant influence on consumer's perceived value of watch $(F=15.244, P=0.000)$, the perceived value of Swiss brand watch is significantly higher than American brand; but not on consumer's perceived value of sport shoes $(F=0.603, P=0.438)$. Made-in country affects consumer's perceived value of both watch and sport shoes ( $F=10.88, P=0.001 ; F=3.338, P=0.069$ ), products (including watch and sport shoes) made in developed countries is perceived with more value than products made in developing countries significantly. Hence a conceptual model was developed in this research on the basis of Dodds's (1991) conceptual model (as show in Fig. 4). 
Table 6 Summary of results

\begin{tabular}{|c|c|c|}
\hline \multirow[t]{2}{*}{ Hypotheses } & \multicolumn{2}{|c|}{ Test results } \\
\hline & Watch & Sport shoes \\
\hline H 1 & $\begin{array}{l}\text { Partly supported, made-in country has } \\
\text { significant effect on product quality } \\
\text { evaluation }\end{array}$ & $\begin{array}{l}\text { Partly supported, made-in country } \\
\text { has significant effect on product } \\
\text { quality evaluation }\end{array}$ \\
\hline H 2 & $\begin{array}{l}\text { Partly supported, brand origin country } \\
\text { has significant effect on purchase } \\
\text { intention }\end{array}$ & Not supported \\
\hline H 3 & $\begin{array}{l}\text { Partly supported, the interaction between } \\
\text { brand origin country and made-in } \\
\text { country significantly affect quality } \\
\text { evaluation, the direction of interaction } \\
\text { is consistent with hypothesis; the } \\
\text { interaction between brand origin } \\
\text { country and made-in country } \\
\text { significantly affect purchase intention, } \\
\text { but direction is not consistent with } \\
\text { hypothesis }\end{array}$ & $\begin{array}{l}\text { Partly supported, the interaction } \\
\text { between brand origin country and } \\
\text { made-in country just affect } \\
\text { purchase intention significantly, } \\
\text { the direction of interaction is not } \\
\text { completely consistent with } \\
\text { hypothesis }\end{array}$ \\
\hline H 4 & Not supported & Not supported \\
\hline
\end{tabular}

Table 7 Consumer's perceived value of watches (mean and rariance)

\begin{tabular}{lcclccc}
\hline & \multicolumn{2}{c}{ Swiss brand } & & \multicolumn{2}{c}{ American brand } \\
\cline { 2 - 3 } & Made in Swiss & Made in China & & Made in America & Made in China & \\
\hline Low price & $4.26(0.92)$ & $4.30(0.93)$ & & $4.31(0.76)$ & $3.69(0.93)$ & $4.14(0.92)$ \\
High price & $4.12(0.94)$ & $3.83(0.81)$ & & $3.70(0.77)$ & $3.04(0.97)$ & $3.68(0.95)$ \\
& $4.19(0.93)$ & $4.07(0.90)$ & & $4.01(0.82)$ & $3.37(1.00)$ & \\
& $4.13(0.91)$ & & $3.69(0.96)$ & $3.91(0.96)$ \\
\hline
\end{tabular}

Table 8 Consumer's perceived value of sport shoes (mean and variance)

\begin{tabular}{|c|c|c|c|c|c|}
\hline & \multicolumn{2}{|c|}{ Swiss brand } & \multicolumn{2}{|c|}{ American brand } & \\
\hline & Made in Swiss & Made in China & Made in America & Made in China & \\
\hline Low price & $4.12(1.19)$ & $3.80(1.09)$ & $4.08(1.01)$ & $3.87(1.10)$ & $3.97(1.10)$ \\
\hline \multirow[t]{3}{*}{ High price } & $3.52(0.91)$ & $3.51(0.99)$ & $3.47(0.75)$ & $3.11(0.87)$ & $3.40(0.89)$ \\
\hline & $3.82(1.09)$ & $3.66(1.04)$ & $3.77(0.94)$ & $3.49(1.05)$ & \\
\hline & \multicolumn{2}{|c|}{$3.74(1.07)$} & \multicolumn{2}{|c|}{$3.63(1.00)$} & $3.68(1.03)$ \\
\hline
\end{tabular}

The pretest indicates that the watch brand origin country images of Swiss and America are significantly different (Swiss is 6.33 and America is 2.45). The difference of brand origin country image does not directly influence consumer's 


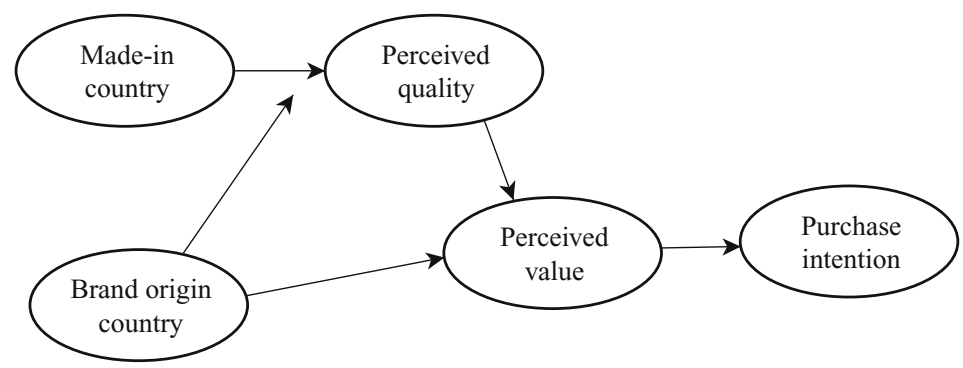

Fig. 4 The conceptual model of the effects of brand origin country and made-in country

watch quality evaluation, but affects consumer's purchase intention through influencing consumer's perceived value. For sport shoes, although Swiss and America have significantly different brand origin country images (Swiss is 2.24; and America is 5.34), this difference does not influence consumer's perceived value (Swiss brand is 3.74; and American brand is 3.63), hence does not influence consumer's purchase intention. Surely, there are so much unknown in the cognition process from brand origin country to perceived value; and the conceptual model still need to be tested in future research.

The results of interaction between brand origin country and made-in country are not consistent across different dependent variables and product types. The interaction effect on consumer's watch quality evaluation is significant; and the direction is as hypothesized. When the watch of good brand origin country image is manufactured in developing countries, consumer's quality evaluation will be significantly lowered compared with developed countries; but this effect is not significant for watch of bad brand origin country image. On the contrary, the interaction effect on consumer's sport shoes quality evaluation is not significant.

When the dependent variable is purchase intention, the interaction effect is also complex. For watch, the direction of interaction is not consistent with hypothesis. The results indicate that consumer's purchase intention is not affected when Swiss brand (good brand origin country image) is manufactured in China compared with in Swiss; but consumer's purchase intention is significantly weakened when American brand (bad brand origin country image) is manufactured in China compared with in America. For sport shoes, it is found that consumer's purchase intention of American brand (good brand origin country image) is significantly weakened when the brand is manufactured in China compared with in America, which supports the hypothesis. Contrary to hypothesis, it is found that consumer's purchase intention of Swiss sport shoes (bad brand origin country image) is significantly strengthened when the brand is manufacture in China compared with in Swiss. Perhaps recent research on consumer's ethnocentrism can provide some explanations (Brodowski, 1998; Han, 1988; Klein, et al., 1998; Wang and Chen, 2004). 
It is found that there is not significant interaction between brand origin country and price in this study. There is no consistent finding about interaction between price and country of origin in the literature. For example, Chao (1993) found that significant interaction between country of origin and price in his study: when country of origin image was good, the effect of price on consumer's perceived quality is not significant; but when country of origin image was bad, there was close association between price and consumer's perceived quality. Differently, Teas and Agarwal (2000) did not find any significant interaction among country of origin and price, brand, or store name. They provided the possible explanation that they presented respondents clear brand and store name in the experiment, which tampered the "Halo effect" of country of origin. In this research, the artificial brands that are not known were provided by most respondents. This design can be seen as a strong test of "Halo effect" of country of origin. In this sense, the results at least partly indicate that brand origin country, made-in country, and price may equally important when consumer evaluates unfamiliar brands, although the mechanism that how brand origin country, made-in country, and price influence consumer's product quality evaluation and purchase intention need to be deeply explored in future research.

Nowadays, international business develops rapidly along globalization process. More and more companies compete in global market. Before they set up brand familiarity or brand reputation, international consumers have few knowledge about the brands hence can not use it to make product quality evaluation and purchase decision. This research reveals that when consumers are not familiar with brand, they will utilize brand origin country and made-in country to evaluate product quality, hence forming purchase intention. Additionally, it is found that brand origin country, made-in country and price are equally important when consumers evaluate unfamiliar brands, which provides valuable implications for those companies that are trying to enter into international market, especially for those companies with inferior brand origin country image or made-in country image. For those companies, traditional strategy of setting low price to offset effect of inferior brand origin country image or made-in country image cannot lift up consumer's quality perception, on the contrary, as this research implies, high price can help companies to improve consumer's perceived quality, hence strengthening purchase intention.

\section{Limitations and future research}

The convenient sampling was used to collect data in this research. Although this method is generally adopted in the field, much care should also be put in order to generalize the conclusions. 
In the discussion part, a conceptual model was proposed to explain the mechanism of effects of brand origin country and made-in country, which should be tested in future research.

Most findings are consistent across different product types: watches and sport shoes, but there are a few inconsistent results needing plausible explanation. Maybe hedonic and utilitarian classification can be introduced in future research. This factor can be manipulated to compare the effects of brand origin country and made-in country in hedonic and utilitarian products. This experimental design may provide more plausible explanation for the effects of brand origin country and made-in country.

Acknowledgements This research is sponsored by National Natural Science Foundation of China (Grant code: 70572021).

\section{References}

Batra R, Venkatram R, Alden D L, Steenkamp J-B E M, Ramachander S (2000). Effects of brand local and nonlocal origin on consumer attitudes in developing countries. Journal of Consumer Psychology, 9(2): 83-95

Belk R W (1975). Situational variables and consumer behavior. Journal of Consumer Behavior, 2(4): $157-164$

Bilkey W J, Nes E (1982). Country-of-origin effect on product evaluation. Journal of International Business Studies, (13): 89-99

Brodowski G H (1998). The effects of country-of-design and country-of-assembly on evaluative beliefs about automobiles and attitudes toward buying them: A comparison between low and high ethnocentric consumers. Journal of International Consumer Marketing, 10(3): 85-113

Chao P (1993). Partitioning country of origin effects: Evaluations of a hybrid product. Journal of International Business Studies, (24): 291-306

Dodds W B, Monroe K B, Grewal D (1991). Effects of price, brand, and store information on buyers' product evaluations. Journal of Marketing Research, 28: 307-319

Erickson G M, Johansson J K, Chao P (1984). Image variables in multi-attribute product evaluations: Country-of-origin effects. Journal of Consumer Research, (11): 694-699

Ettenson R (1993). Brand name and country of origin effects in the emerging market economies of Russia, Poland and Hungary. International Marketing Review, 10(5): 14-36

Gabrielle K J, Ettenson R (1999). Consumer animosity and consumer ethnocentrism: An analysis of unique antecedents. Journal of International Consumer Marketing, (11): 5-25

Han C M (1988). The role of consumer patriotism in the choice of domestic versus foreign products. Journal of Advertising Research, (28): 25-31

Han C M (1989). Country image: Halo or summary constructs? Journal of Marketing Research, 26(3): 222-229

Hong Sung-Tai, Robert S, Wyer R S Jr (1989). Effects of country-of-origin and productattribute information on product evaluation: An information processing perspective. Journal of Consumer Research, (16): 175-187 
Johansson J K (1989). Determinants and effects of the use of "made in" labels. International Marketing Review, 6(1): 47-59

Klein G J, Ettenson R (1999). Consumer animosity and consumer ethnocentrism: An analysis of unique antecedents. Journal of International Consumer Marketing, (11): 5-25

Klein J G, Ettenson R, Morris M D (1998). The animosity model of foreign product purchase: An empirical test in the people's republic of China. Journal of Marketing, (62): 89-100

Lambert Z V (1972). Price and Choice Behavior. Journal of Marketing Research, 9: 35-40

Leavitt H J (1954). A note on some experimental findings about the meaning of price. The Journal of Business, (27): 205-210

Liefeld J P, Heslop L A, Papdopolous N, Wall M (1996). Dutch consumer use of intrinsic, country-or-origin, and price cues in product evaluation and choice. Journal of International Consumer Marketing, 9(1): 57-81

Loureiro M, Umberger W J (2003). Estimating consumer willingness to pay for countryof-origin labeling. Journal of Agricultural and Resource Economics, (28): 287-301

Mahaswaran D (1994). Country of origin as a stereotype: Effects of consumer expertise and attribute strength on product evaluations. Journal of Consumer Research, (21): 354-364

McConnell J D (1968). An experimental examination of the price-quality relationship. The Journal of Business, (41): 439-444

Nebenzahl I D, Jaffe E D, Lampert S I (1997). Towards a theory of country image effect on product evaluation. Management International Review, (37): 27-49

Peterson R A, Jolibert A J P (1995). A meta-analysis of country-of-origin effects. Journal of International Business Studies, (26): 883-898

Phau I, Prendergast G (2000). Conceptualizing the country of origin of brand. Journal of Marketing Communications, (6): 159-170

Rao A R, Monroe K B (1988). The moderating effect of prior knowledge on cue utilization in product evaluation. Journal of Consumer Research, (15): 253-264

Rao A R, Monroe K B (1989). The effect of price, brand name, and store name on buyers' perceptions of product quality: An integrative review. Journal of Marketing Research, (26): $351-357$

Reierson C C (1967). Attitude changes toward foreign products. Journal of Marketing Research, (4): $385-387$

Schooler R D (1965). Product bias in the central american common market. Journal of Marketing Research, (2): 394-397

Teas R K, Agarwal S (2000). The effects of extrinsic product cues on consumers' perceptions of quality, sacrifice, and value. Journal of the Academy of Marketing Science, 28(2): $278-290$

Wang Chenglu, Chen Zhenxiong (2004). Consumer ethnocentrism and willingness to buy domestic products in a developing country setting: Testing moderating effect. Journal of Consumer Marketing, 21(6): 391-397

Zeithaml V A (1988). Consumer perceptions of price, quality, and value: A means-end model and synthesis of evidence. Journal of Marketing, 52(7): 2-22 